\title{
ACCUMULATION OF FERTILIZER PHOSPHORUS IN PEAT SOILS
}

\author{
Armi Kaila and Hilve Missilä \\ Department of Agricultural Chemistry, University of Helsinki
}

Received April 3, 1956.

The fate of fertilizer phosphorus in soils forms an interesting problem which is of importance both to the practical farmer and to the soil scientist. It is known that generally only a relatively small part of the mineral phosphorus applied as fertilizers is in the first year utilized by the crops. The residual effect of phosphate fertilizers may sometimes be considerable and it may last for several years, whereas in other cases even the response in the year of application can be negligible in spite of a distinct lack of available P. Obviously, this different behaviour largely depends on the kind and intensity of the phosphate fixation by the different soils.

Comprehensive literature concerning the retention of phosphates by soil is accumulated, and it has been attempted to elucidate the forms in which the residual phosphate occurs (cf. 11, 14, etc.). As it can be expected, most attention has been paid to the mineral soils and only in a few cases peat soils have been studied. Therefore, our information of the fertilizer $\mathrm{P}$ in peat soils is even scarcer than the knowledge we suppose we have of this problem in mineral soils.

McCool (13) states that the peat and muck soils of Michigan vary considerably in their ability to take up phosphate: soils low in ash possessed a very small capacity in this respect; in other soils this property increased with mineral content and degree of decomposition. Doughty (2) reports that in his material the formation of iron, aluminium and calcium phosphates will account for the fixation of phosphate under field conditions. In another paper Doughty (3) emphasizes the importance of iron in the retention of phosphate. KASAKOw (10) finds that the maximum fixation of phosphate in peat soils occurs in the range of $\mathrm{pH} 2-3$ and that lowmoor peat adsorbs more $\mathrm{P}$ than highmoor peat, probably owing to the higher iron, aluminium and calcium content of the former.

The direct role of organic matter in the retention of phosphate is supposed to be small; generally the assumption is held that humic acids and other organic acids are able to prevent the fixation of phosphate by iron complexes (1, 12 etc.). 
However, the indirect effect of organic matter may sometimes be noteworthy, i. e. the organic matter can serve as a source of energy for the microorganisms and thus cause biological absorption of $\mathrm{P}$. This, as yet, is only a supposition which has not been proved under common conditions in the field, but as already previously mentioned (6) in peat soils with a low degree of humification it may play some role. The data in the same paper indicated that during the ten years of an experiment the total content of organic $\mathrm{P}$ in a limed lowmoor peat soil increased due to the $\mathrm{P}$ fertilizers, and even more intensively than the corresponding content of inorganic P. JACKMAN $(4,5)$ has found a rather marked conversion of applied $\mathrm{P}$ into organic forms also in mineral soils. Probably both higher plants and microorganisms are responsible for this accumulation of organic $P$.

The role of organic $\mathrm{P}$ in the accumulation of fertilizer $\mathrm{P}$ in peat soils seems to be worth further investigation. Since some samples from field experiments on peat soils were available, an attempt was made to elucidate this problem. In addition to the analyses of organic $\mathrm{P}$ also the solubility of accumulated inorganic $\mathrm{P}$ was studied.

\section{Material and methods}

Samples from a 30-years-old field experiment with increasing applications of phosphate fertilizers were available. This experiment of the Peat Experiment Station in Leteensuo was arranged on a well humified lowmoor peat clayed with $200 \mathrm{~m}^{3} /$ ha and annually fertilized with muriate of potash. The four samples originated from plots annually dressed with superphosphate in amounts corresponding to $0,20,40$ and $60 \mathrm{~kg} / \mathrm{ha}$ of $\mathrm{P}_{2} \mathrm{O}_{5}$ respectively.

The second group of samples originates from 12 fertilization experiments on newly reclaimed soils in Northern Finland. They represent various kinds of peat lands without any mixing with mineral matter. The experiments were approximately four years old. The samples were taken from plots with no treatment and from plots annually fertilized with $150 \mathrm{~kg}$ of calcium nitrate, $200 \mathrm{~kg}$ of superphosphate, and $120 \mathrm{~kg}$ of muriate of potash per hectar.

The phosphorus analyses were performed by the molybdenum blue method modified by the author (7). Total $\mathrm{P}$ was estimated from a Kjeldahl digest in which copper sulphate and potassium sulphate were substituted by sodium selenite and sodium sulphate. Organic P was determined as an average of the results obtained by an acid-alkali extraction and by an ignition method (9).

The easily soluble inorganic P was estimated in different ways. Extractions with distilled water, $0.05 \mathrm{~N}$ sodium chloride, $0.5 \mathrm{~N}$ acetic acid, $1 \%$ citric acid, and $0.2 \mathrm{~N}$ sulphuric acid were performed. The time of extraction was one hour and the ratio of soil to solution was $1: 20$ in the water, sodium chloride, acetic acid and citric acid extractions and 1: 100 in the extraction with sulphuric acid. The amounts of inorganic $\mathrm{P}$ soluble in $4 \mathrm{~N}$ sulphuric acid and in the following extraction with cold and hot $0.5 \mathrm{~N}$ sodium hydroxide, obtained in connection with the determination of total organic $\mathrm{P}$ are also reported.

The solubility of inorganic and organic $\mathrm{P}$ at various $\mathrm{pH}$ levels was studied by extractions performed in the ratio of $1: 20$ and with mixtures of $0.05 \mathrm{~N}$ hydrochloric acid and $0.05 \mathrm{~N}$ sodium hydroxide. The amount of organic $\mathrm{P}$ dissolved by these treatments was estimated as the difference between the total $\mathrm{P}$ in the solution digested with perchloric acid and the inorganic $\mathrm{P}$ measured directly from the extract. The $\mathrm{pH}$ was first determined by a Beckman $\mathrm{pH}$-meter with glass electrode from the extract and from the wet soil on the filter. Later only the $\mathrm{pH}$-value of the clear extract was measured, because the differences of corresponding values appeared to be almost insignificant.

The retention of phosphate against $0.05 \mathrm{~N}$ sodium chloride was estimated as the difference of the amounts of $\mathrm{P}$ in extracts with and without an application of potassium monophosphate into the extractant. The ratio of soil to solution was $1: 20$ and the extraction period was one hour. 
Iron was determined colorimetrically with rhodanide. An aliquot of the solution to be analysed was diluted with $20 \mathrm{ml}$ of $0.5 \mathrm{~N}$ hydrochloric acid and water to $45 \mathrm{ml} .5 \mathrm{ml}$ of $3 \mathrm{~N}$ potassium rhodanide was added. The colour intensity was measured by a Lumetron colorimeter using a green filter with the transmission peak at $515 \mathrm{~m} \mu$.

The $\mathrm{pH}$ of the original samples was determined from water suspension (1:4) using the Beckman pH-meter. The volume weight was estimated by an apparatus explained elsewhere (8).

\section{Results}

\section{a. The Leteensuo-experiment}

Attention is first paid to the 30 -years-old field experiment from Leteensuo. The total $\mathrm{P}$, inorganic $\mathrm{P}$ and organic $\mathrm{P}$ content of the plots annually dressed with $0,20,40$ or $60 \mathrm{~kg} /$ ha of $\mathrm{P}_{2} \mathrm{O}_{5}$ applied as superphosphate is reported in Table 1 .

With the increasing application of phosphate an increase in the accumulation of total, inorganic and organic $\mathrm{P}$ content of the peat samples can be stated. The proportion of organic $\mathrm{P}$ of total $\mathrm{P}$ is the lower the higher the $\mathrm{P}$ dressing, but the organic $\mathrm{P}$ content of organic dry matter tends to grow.

Theoretically it is not right, of course, to assume that the difference in the $\mathrm{P}$ content of the samples from the fertilized plots and in that from the untreated one would indicate the amount of fertilizer $\mathrm{P}$ accumulated in the particular plots. Unfortunately, the data for the yields and their $\mathrm{P}$ content in the 30 years are not available, and it is impossible to compute the real $\mathrm{P}$ balance of the variously treated plots. Therefore, it must be supposed that the differences in the $\mathrm{P}$ content of the samples can yield some information of the changes in the $\mathrm{P}$ conditions of this peat soil due to the application of superphosphate.

The total amounts of phosphorus applied to the various plots during 30 years correspond to about 250,500 and $750 \mathrm{ppm}$ respectively, expressed as $\mathrm{P}$. The increase in the total $\mathrm{P}$ content of the respective plots as compared with the 0 -plot appears to be 150,410 and $550 \mathrm{ppm}$, which means that about $100 \mathrm{ppm}$ of $\mathrm{P}$ in the plots 2 and 3 , and about $200 \mathrm{ppm}$ of $\mathrm{P}$ in the plot 4 have been utilized by the crops, or in some other way, got out of the ploughing layer. Probably it is too dangerous to try on the basis of these figures to estimate the part of fertilizer $\mathrm{P}$ accumulated in the soil. These percentages would be 60,80 and 75 per cent of the total amount

Table 1. Total, inorganic and organic phosphorus in the samples from the experiment in Leteensuo.

\begin{tabular}{|c|c|c|c|c|c|c|c|c|}
\hline & Annual & & & Total P & Inorg. $\mathrm{P}$ & is. & Org. P & \\
\hline Number & $\begin{array}{l}\text { treatment } \\
\mathrm{P}_{2} \mathrm{O}_{5} \mathrm{~kg} / \mathrm{ha}\end{array}$ & $\mathrm{pH}$ & $\begin{array}{l}\text { Volume } \\
\text { weight }\end{array}$ & ppm & ppm & ppm & $\begin{array}{c}\% \text { of } \\
\text { total } \mathrm{P}\end{array}$ & $\begin{array}{c}\text { org. dry } \\
\text { matter }\end{array}$ \\
\hline 1 & 0 & 4.4 & 0.54 & 1040 & 260 & 780 & 75 & 0.13 \\
\hline 2 & 20 & 4.6 & 0.54 & 1190 & 330 & 860 & 72 & 0.15 \\
\hline 3 & 40 & 4.7 & 0.53 & 1450 & 430 & 1020 & 70 & 0.16 \\
\hline 4 & 60 & 4.7 & 0.52 & 1590 & 500 & 1090 & 69 & 0.17 \\
\hline
\end{tabular}


Table 2. Inorganic phosphorus soluble on various extractants in the samples from the experiment in Leteensuo.

(Expressed as P ppm.)

\begin{tabular}{|c|c|c|c|c|c|c|}
\hline Number & $\mathrm{H}_{2} \mathrm{O}$ & $\begin{array}{c}\text { Acetic aci } \\
0.5 \mathrm{~N}\end{array}$ & $\begin{array}{c}\text { Citric acid } \\
1 \%\end{array}$ & $\begin{array}{l}\mathrm{H}_{2} \mathrm{SO}_{4} \\
0.2 \mathrm{~N}\end{array}$ & $\begin{array}{l}\text { In acid-alka } \\
4 \mathrm{~N} \mathrm{H}_{2} \mathrm{SO}_{4}\end{array}$ & $\begin{array}{l}\text { li extraction } \\
0.5 \mathrm{~N} \mathrm{NaOH}\end{array}$ \\
\hline 1 & 2 & 2 & 30 & 90 & 180 & 80 \\
\hline 2 & 2 & 2 & 30 & 110 & 230 & 100 \\
\hline 3 & 2 & 4 & 50 & 120 & 300 & 130 \\
\hline 4 & 3 & 5 & 70 & 220 & 370 & 130 \\
\hline
\end{tabular}

applied to the plots with 20,40 , and $60 \mathrm{~kg} / \mathrm{ha}$ of $\mathrm{P}_{2} \mathrm{O}_{5}$ respectively. This would correspond to a utilization of phosphorus at the rate of 40 per cent of the annually given $20 \mathrm{~kg} / \mathrm{ha}$ of $\mathrm{P}_{2} \mathrm{O}_{5}$ or $110 \mathrm{~kg} / \mathrm{ha}$ of superphosphate, and at the rate of $20-25$ per cent when the application was three times or twice as high as that.

The increase in the total $\mathrm{P}$ content of the soil due to the fertilization appears both in the inorganic and organic $\mathrm{P}$ contents. As compared with the plot without treatment the plots which have received 20,40 , or $60 \mathrm{~kg} /$ ha of $\mathrm{P}_{2} \mathrm{O}_{5}$ show a respective increase of 70,170 and $240 \mathrm{ppm}$ of $\mathrm{P}$ in the inorganic $\mathrm{P}$ fraction whereas the corresponding increase in the organic $\mathrm{P}$ complex appears to be about 80,240 and 310 $\mathrm{ppm}$ respectively. Thus a somewhat higher amount of $\mathrm{P}$ has been accumulated in the organic form than in the inorganic fraction. Probably this turning over into organic compounds is brought about not only by the biological absorption of microorganisms but also by the accumulation of organic $\mathrm{P}$ compounds in the remains of plants. It is possible that, in this connection, the way through the plants is the more important one.

The amounts of inorganic $\mathrm{P}$ in water or in $0.5 \mathrm{~N}$ acetic acid extracts are low in all the samples (Table 2). A slight tendency to higher values with the increasing application of $\mathrm{P}$ may be observed. This tendency is more distinct in the amounts extracted by $1 \%$ citric acid and $0.2 \mathrm{~N}$ sulphuric acid. It is of interest to notice that in the acid-alkali extraction the greater part of total inorganic $\mathrm{P}$ is already dissolved by the $4 \mathrm{~N}$ sulphuric acid. The differences in the amount of inorganic $\mathrm{P}$ in the following sodium hydroxide extracts are low.

The amounts of inorganic $\mathrm{P}$ extracted at different $\mathrm{pH}$-levels (Table 3 ) show a minimum at $\mathrm{pH} 4.2$ in all the samples. In this respect a resemblance with the solubility of vivianite may be detected; in a sample of vivianite the following amounts of inorganic P were extracted using the same method as for the analyses of the peat samples:

$$
\begin{aligned}
& \text { at } \mathrm{pH} 1.5 \quad \mathrm{pH} 2.5 \quad \mathrm{pH} 4.4 \quad \mathrm{pH} 4.6 \quad \mathrm{pH} 7.8 \quad \mathrm{pH} 8.6 \\
& 940 \mathrm{ppm} \quad 190 \mathrm{ppm} \quad 20 \mathrm{ppm} \quad 140 \mathrm{ppm} \quad 780 \mathrm{ppm} 2750 \mathrm{ppm}
\end{aligned}
$$

This, of course, is not enough to prove that inorganic $\mathrm{P}$ in this peat soil would occur as compounds similar to vivianite, but it corroborates the view that iron complexes may play an important role in the retention of inorganic $\mathrm{P}$ in soils of this kind. 
Table 3. Inorganic and organic $\mathrm{P}$ extracted at various $\mathrm{pH}$-levels from samples of the Leteensuo-experiment.

\begin{tabular}{|c|c|c|c|c|c|c|c|c|c|c|}
\hline \multirow{2}{*}{ Number } & \multicolumn{5}{|c|}{ Inorganic $\mathrm{P}$ ppm soluble at $\mathrm{pH}$} & \multicolumn{5}{|c|}{ Organic $\mathrm{P}$ ppm soluble at $\mathrm{pH}$} \\
\hline & 2.4 & 4.2 & 6.1 & 7.3 & 8.6 & 2.4 & 4.2 & 6.1 & 7.3 & 8.6 \\
\hline 1 & 8 & 1 & 5 & 5 & 11 & 8 & 6 & 35 & 83 & 189 \\
\hline 2 & 7 & 1 & 7 & 9 & 19 & 10 & 7 & 38 & 89 & 295 \\
\hline 3 & 9 & 2 & 9 & 12 & 33 & 9 & 9 & 48 & 119 & 355 \\
\hline 4 & 11 & 2 & 12 & 19 & 50 & 10 & 10 & 49 & 116 & 381 \\
\hline
\end{tabular}

Even at $\mathrm{pH} 8.6$ the amount of inorganic $\mathrm{P}$ extracted is rather low corresponding to about $6,6,9$, and 10 per cent of the total inorganic $\mathrm{P}$ in the samples $1,2,3$, and 4 respectively. This soil appears to fix inorganic $\mathrm{P}$ rather tenaceously. The retention of phosphate against an extraction with $0.05 \mathrm{~N}$ sodium chloride at $\mathrm{pH} 4.2$ was so high that about 95 per cent of the inorganic $\mathrm{P}$ in the solution was adsorbed, even when the amount of $\mathrm{P}$ applied as potassium monophosphate was $10 \mathrm{mg} / \mathrm{l}$ which corresponded to $200 \mathrm{ppm}$ of the soil.

In Table 3 also the amounts of organic $\mathrm{P}$ extracted at various $\mathrm{pH}$-levels are reported. Under acid conditions the solubility of organic P compounds was low, but at $\mathrm{pH} 6$ the amounts began to increase and a considerable part of the total organic $\mathrm{P}$ was dissolved at $\mathrm{pH}$ 8.6. If again some daring estimations are made, it may be found that at $\mathrm{pH} 8.6$ about 11,13 , and 16 per cent of the inorganic $\mathrm{P}$ accumulated owing to the fertilization with annual amounts of 20,40 and $60 \mathrm{~kg} / \mathrm{ha}$ of $\mathrm{P}_{2} \mathrm{O}_{5}$ are dissolved whereas the corresponding percentages for the organic part are 100,70 and 60 per cent, respectively. A similar relationship appears to exist between the amounts of inorganic and organic $\mathrm{P}$ extracted also at the other $\mathrm{pH}$-levels. Thus, the accumulated organic $\mathrm{P}$ may be slightly more soluble than the residual $\mathrm{P}$ accumulated as inorganic forms. This, again, is a conclusion which needs more material for evidence.

\section{b. The field experiments on newly reclaimed soils}

Table 4 shows the various kinds of peat and peat land types which the 12 experiments represent. The degree of land quality (Bo) ranges from 1 to 8 . In practice the classes from 5 to 10 are considered tillable. The total $\mathrm{P}$ content of the samples from the untreated plots ranges from 390 to $1410 \mathrm{ppm}$, and without exception the plots which have received phosphate fertilizer show a higher total $\mathrm{P}$ content, although in the experiments 1 and 9 the difference is almost insignificant. In all the experiments, except in number 3 , the samples from the PKN-plots contain more inorganic $\mathrm{P}$ than the untreated ones. The difference in the organic $\mathrm{P}$ content between the variously treated plots is less regular. In two of the experiments, numbers 5 and 9 , even a lower organic $\mathrm{P}$ content can be stated for the PKN-plots, in numbers 1 and 10 there is no difference, and in some others the increase in the organic $\mathrm{P}$ content is markedly lower than that in the inorganic $\mathrm{P}$ content. 
Table 4. Total, inorganic and organic $\mathrm{P}$ in the samples from the field experiments on newly reclaimed soil.

\begin{tabular}{|c|c|c|c|c|c|c|}
\hline & Treat- & & & Inorg. $\mathrm{P}$ & & Drg. P \\
\hline & ment & $\mathrm{pH}$ & ppm & ppm & ppm & $\%$ of total $\mathrm{P}$ \\
\hline 1. Sphagnum fuscum bog .... & 0 & 4.2 & 390 & 80 & 310 & 80 \\
\hline $\mathrm{Sp}, \mathrm{H}_{3}$, Bo $1 \ldots \ldots \ldots \ldots$ & PKN & 4.3 & 410 & 110 & 300 & 73 \\
\hline 2. Sph. cuspidatum bog .... & 0 & 4.5 & 520 & 140 & 380 & 73 \\
\hline $\mathrm{Sp}, \mathrm{H}_{2-3}$, Bo $1-2 \quad \ldots \ldots$ & PKN & 4.3 & 680 & 170 & 510 & 75 \\
\hline 3. Treeless Carex bog $\ldots \ldots$ & 0 & 4.8 & 960 & 220 & 740 & 77 \\
\hline $\mathrm{CSp}, \mathrm{H}_{3}$, Во $3 \ldots \ldots \ldots$ & PKN & 4.4 & 1080 & 200 & 880 & 81 \\
\hline 4. Sph. papillosum bog ...... & 0 & 5.3 & 390 & 110 & 280 & 72 \\
\hline $\mathrm{SCp}, \mathrm{H}_{4}$, Bo $6 \quad \ldots \ldots \ldots$ & PKN & 5.3 & 540 & 160 & 380 & 70 \\
\hline 5. Mesotrophic rimpi bog .... & 0 & 5.0 & 1410 & 410 & 1000 & 71 \\
\hline $\mathrm{SC}_{\mathrm{p}}, \mathrm{H}_{4}$, Bo $6 \ldots \ldots \ldots \ldots$ & $\mathrm{PKN}$ & 5.0 & 1610 & 690 & 920 & 57 \\
\hline 6. Carex limosa rimpi bog $\ldots$ & 0 & 4.6 & 550 & 130 & 420 & 76 \\
\hline $\mathrm{Cp}, \mathrm{H}_{3-4}$, Bo $5 \ldots \ldots \ldots$ & $\mathrm{PKN}$ & 4.6 & 810 & 200 & 610 & 75 \\
\hline 7. Carex limosa rimpi bog $\ldots$ & 0 & 4.8 & 570 & 80 & 490 & 86 \\
\hline $\mathrm{Cp}, \mathrm{H}_{5}$, Bo $5 \ldots \ldots \ldots \ldots$ & $\mathrm{PKN}$ & 4.6 & 810 & 140 & 670 & 83 \\
\hline 8. Rimpi bog $\ldots \ldots \ldots \ldots \ldots$ & 0 & 5.2 & 500 & 120 & 380 & 76 \\
\hline $\mathrm{Cp}, \mathrm{H}_{4}$, Bo $6 \ldots \ldots \ldots \ldots$ & PKN & 4.9 & 790 & 290 & 500 & 63 \\
\hline 9. Sph. Warnstorfianum fen .. & 0 & 5.5 & 510 & 80 & 430 & 84 \\
\hline EuSCp, $H_{4}$, Bo $8 \ldots \ldots \ldots$ & $\mathrm{PKN}$ & 5.3 & 520 & 130 & 390 & 75 \\
\hline 10, Sph. Warnstorfianum fen .. & 0 & 5.0 & 930 & 130 & 80 & 86 \\
\hline EuSCp, $H_{4}$, Bo $8 \ldots \ldots \ldots$ & PKN & 4.8 & 1230 & 440 & 790 & 64 \\
\hline 11. Birch fen $\ldots \ldots \ldots \ldots \ldots$ & 0 & 5.3 & 1120 & 220 & 900 & 80 \\
\hline $\mathrm{BCp}, \mathrm{H}_{4}$, Bo $8 \ldots \ldots \ldots$ & PKN & 5.3 & 1520 & 490 & 1030 & 68 \\
\hline 12. Birch fen $\ldots \ldots \ldots \ldots \ldots$ & 0 & 5.1 & 1120 & 300 & 820 & 73 \\
\hline $\mathrm{BCp}, \mathrm{H}_{4-5}$, Bo $8 \ldots \ldots$ & $\mathrm{PKN}$ & 4.9 & 1490 & 630 & 860 & 58 \\
\hline
\end{tabular}

The fact must be remembered that in field experiments of this kind arranged on newly reclaimed peat soils the variation and the errors may be marked. Therefore, even if the samples were carefully taken they may not give a reliable picture of the differences in the variously treated plots. Particularly the fact that in peat soils the yield of the 0-plot may often be very low as compared with that of the PKN-plot violates the conclusions drawn on the basis of the analyses obtained. Yet, it appears that in several experiments the application of fertilizer has led to an increase both in the inorganic and organic $\mathrm{P}$ contents of peat even within this rather short experimental period.

As to the solubility of inorganic $\mathrm{P}$ in these samples it can be stated (Table 5) that the effect of fertilization is revealed by the data obtained, particularly when citric acid or sulphuric acid was employed as extractant. In the amounts of most easily soluble P the difference between the 0-plot and the PKN-plot is not always 
Table 5. Inorganic P extracted by various solvents from the samples of the field experiments on newly reclaimed soils (Expressed as $\mathrm{P}$ ppm).

\begin{tabular}{|c|c|c|c|c|c|c|c|c|}
\hline Number & $\begin{array}{l}\text { Kind } \\
\text { of } \\
\text { peat }\end{array}$ & $\begin{array}{l}\text { Treat- } \\
\text { ment }\end{array}$ & $\begin{array}{c}\mathrm{NaCl} \\
0.05 \mathrm{~N}\end{array}$ & $\begin{array}{c}\text { Acetic acid } \\
0.5 \mathrm{~N}\end{array}$ & $\begin{array}{c}\text { Citric acid } \\
1 \%\end{array}$ & $\begin{array}{l}\mathrm{H}_{2} \mathrm{SO}_{4} \\
0.2 \mathrm{~N}\end{array}$ & $\begin{array}{l}\text { In acid-alkal } \\
4 \mathrm{~N} \mathrm{H}_{2} \mathrm{SO}_{4}\end{array}$ & $\begin{array}{l}\text { li extraction } \\
0.5 \mathrm{~N} \mathrm{NaOH}\end{array}$ \\
\hline \multirow[t]{2}{*}{1.} & $\mathrm{Sp}$ & 0 & 14 & 16 & 17 & 20 & 30 & 50 \\
\hline & & PKN & 40 & 37 & 44 & 40 & 70 & 40 \\
\hline \multirow[t]{2}{*}{2.} & $\mathrm{Sp}$ & 0 & 13 & 16 & 35 & 30 & 50 & 90 \\
\hline & & PKN & 17 & 21 & 37 & 60 & 70 & 100 \\
\hline \multirow[t]{2}{*}{3.} & $\mathrm{CSp}$ & 0 & 2 & 6 & 17 & 20 & 30 & 190 \\
\hline & & PKN & 3 & 6 & 22 & 30 & 50 & 140 \\
\hline \multirow[t]{2}{*}{4.} & $\mathrm{SCp}$ & 0 & 2 & 7 & 18 & 30 & 40 & 70 \\
\hline & & PKN & 8 & 15 & 36 & 50 & 70 & 90 \\
\hline \multirow[t]{2}{*}{5.} & $\mathrm{SCp}$ & 0 & 1 & 4 & 41 & 270 & 240 & 170 \\
\hline & & $\mathrm{PKN}$ & 1 & 9 & 198 & 370 & 540 & 160 \\
\hline \multirow[t]{2}{*}{6.} & $\mathrm{Cp}$ & 0 & 1 & 5 & 13 & 20 & 30 & 80 \\
\hline & & PKN & 2 & 11 & 43 & 80 & 100 & 110 \\
\hline \multirow[t]{2}{*}{7.} & $\mathrm{Cp}_{\mathrm{p}}$ & 0 & 4 & 7 & 14 & 20 & 20 & 80 \\
\hline & & $\mathrm{PKN}$ & 2 & 6 & 16 & 30 & 50 & 90 \\
\hline \multirow[t]{2}{*}{8.} & $\mathrm{Cp}$ & 0 & 0 & 3 & 17 & 20 & 120 & 90 \\
\hline & & PKN & 1 & 5 & 31 & 140 & 160 & 110 \\
\hline \multirow[t]{2}{*}{9.} & EuSCp & 0 & 8 & 9 & 16 & 20 & 30 & 50 \\
\hline & & PKN & 9 & 16 & 47 & 70 & 80 & 40 \\
\hline \multirow[t]{2}{*}{10.} & $\mathrm{EuSC}_{\mathrm{p}}$ & 0 & 1 & 2 & 13 & 20 & 30 & 100 \\
\hline & & PKN & 4 & 10 & 130 & 260 & 320 & 100 \\
\hline \multirow[t]{2}{*}{11.} & $\mathrm{BCp}$ & 0 & 1 & 2 & 10 & 20 & 70 & 120 \\
\hline & & PKN & 1 & 2 & 24 & 130 & 330 & 100 \\
\hline \multirow[t]{2}{*}{12.} & $\mathrm{BC} p$ & 0 & 0 & 2 & 18 & 70 & 160 & 140 \\
\hline & & PKN & 0 & 2 & 27 & 130 & 480 & 150 \\
\hline
\end{tabular}

quite distinct, and also the inorganic $\mathrm{P}$ dissolved by $0.5 \mathrm{~N}$ sodium hydroxide after the treatment with $4 \mathrm{~N}$ sulphuric acid appears to change insignificantly owing to the fertilization. These may be explained supposing that the easily available part of applied $\mathrm{P}$ has been taken up by the crop, and on the other hand, that the soil has not yet been able to fix fertilizer-P so tenaceously that it would be left into the alkali soluble fraction of the acid-alkali extraction.

In the Sp-samples the solubility of both native and applied inorganic $\mathrm{P}$ in the weak solvents appears to be higher than that in the samples of peat of better qualities, in general. The retention of applied $\mathrm{P}$ against an extraction with $0.05 \mathrm{~N}$ sodium chloride also characterizes the intensity of the fixation in these sam- 
Table 6. Retention of phosphate against. $0.05 \mathrm{~N} \mathrm{NaCl}$ and iron soluble in $0.1 \mathrm{~N} \mathrm{HCl}$ in samples of the experiments in newly reclaimed soil.

\begin{tabular}{|c|c|c|c|c|}
\hline & \multicolumn{3}{|c|}{$\begin{array}{c}\text { Percentage of } \mathrm{P} \text { adsorbed from solutions } \\
\text { containing }\end{array}$} & \multirow[t]{2}{*}{$\begin{array}{c}\text { Fe } \\
\text { ppm }\end{array}$} \\
\hline & $1 \mathrm{mg} / \mathrm{l}$ & $5 \mathrm{mg} / \mathrm{l}$ & $10 \mathrm{mg} / \mathrm{l}$ & \\
\hline 1. $\mathrm{Sp}$ & 18 & 7 & 3 & 10 \\
\hline 2. $\mathrm{Sp}$ & 59 & 51 & 46 & 10 \\
\hline 3. $\mathrm{CSp}$ & 80 & 75 & 70 & 40 \\
\hline 4. $\mathrm{SC}_{\mathrm{p}}$ & 58 & 50 & 45 & 10 \\
\hline 5. $\mathrm{SC}_{\mathrm{p}}$ & 96 & 95 & 94 & 240 \\
\hline 6. $\mathrm{Cp}$ & 85 & 79 & 75 & 20 \\
\hline 7. $\mathrm{Cp}$ & 69 & 62 & 56 & 20 \\
\hline 8. $\mathrm{Cp}$ & 90 & 81 & 75 & 150 \\
\hline 9. $\mathrm{EuSC}_{\mathrm{p}}$ & 58 & 48 & 43 & 30 \\
\hline 10. $\mathrm{EuSC}_{\mathrm{p}}$ & 92 & 91 & 88 & 160 \\
\hline 11. $\mathrm{BCp}$ & 99 & 99 & 99 & 360 \\
\hline 12. $\mathrm{BCp}$ & 97 & 98 & 94 & 320 \\
\hline
\end{tabular}

ples. These data are reported in Table 6 which also contains amounts of iron extracted by $0.1 \mathrm{~N}$ hydrochloric acid. Since between the results obtained for the samples of the 0-plots and PKN-plots no significant difference was observed; the average quantities are listed. The retention of phosphate appears to vary markedly but it is rather high in most of the samples. Only the Sphagnum fuscum peat in the experiment 1 cannot adsorb much phosphate. On the other hand, there are samples, from the experiments $5,10,11$, and 12 , which are able to fix almost all of the phosphate in the solution, even when its original $\mathrm{P}$ concentration was $10 \mathrm{mg} / 1$ or corresponded to $200 \mathrm{mg} / \mathrm{kg}$ of the peat sample. Generally, the part of phosphate fixed by the samples during the extraction decreases with the increase in phosphate concentration of the solution, but in most of the samples this decrease is far less than could be expected.

The content of iron soluble in $0.1 \mathrm{~N}$ hydrochloric acid appears to be rather closely connected with the fixation capacity of the samples. The correlation coefficient calculated between the percentic retention of $\mathrm{P}$ from the solution containing $10 \mathrm{mg} / \mathrm{l}$ of $\mathrm{P}$ and the amount of iron dissolved by the hydrochloric acid treatment is $\mathrm{r}=0.778^{*}$. This, of course, is not enough to prove that the iron complexes would be the main factors in the fixation of phosphate ion by these peat soils. It must also be emphasized that the results obtained for the retention of phosphate do not represent the conditions under equilibrium. To reach that probably a far longer period of treatment would be necessary.

The amount of inorganic and organic $\mathrm{P}$ extracted from these samples at various $\mathrm{pH}$-levels were also estimated. The results obtained were well in accordance with the data from the Leteensuo-experiment and with the other information of the present samples. The minimum amounts of inorganic $\mathrm{P}$ were extracted both from the treated and untreated samples mostly at about $\mathrm{pH} 3.5-4.0$, but in some soils 
the lowest results were found at $\mathrm{pH} 2.5-3.0$. In the experiment number 9 the minimum appeared to lie at $\mathrm{pH}$ 7. Yet, in all the samples the solubility was highest in the alkaline reaction which shows that calcium phosphates do not play any important role in these peat soils.

\section{Discussion}

The results reported in the present paper give only an incomplete answer to the question of the forms in which fertilizer $\mathrm{P}$ may accumulate in peat soils. The quality of the material allows, at the most, an orientation.

It appears, however, to be evident that the application of phosphate fertilizers leads to an increase also in the organic $\mathrm{P}$ content of peat soils. Strictly speaking the results obtained only prove that the organic $\mathrm{P}$ content of peat from a plot which have received phosphate fertilizer tends to be higher than that of corresponding peat from a plot without P-application. This, of course, may be accounted either to an increase in the organic $\mathrm{P}$ content of the former or to a mineralization of native organic $\mathrm{P}$ in the latter. In this case the former supposition seems to be more probable.

This biological absorption of $\mathrm{P}$ performed by microorganisms and higher plants may turn over to organic forms more than half of the phosphate applied as fertilizers as was pointed out by the figures obtained from the old field experiment in Leteensuo. It is difficult to estimate how rapidly this accumulation of organic $\mathrm{P}$ occurs in different soils. The experiments on newly reclaimed peat soils indicate that sometimes, particularly in experiments on BCp and EuSCp as well as on Sphagnum fuscum peat, the fertilizer $\mathrm{P}$ tends largely to be accumulated as inorganic forms during the first years. On the other hand, in experiments on $\mathrm{Cp}$ and CSp an accumulation as organic compouds seems to be quite marked.

Since no information of the yields and the $\mathrm{P}$ content of the various crops was available no conclusion on the ability of the plant to take up $\mathrm{P}$ from the various fractions in soil can be drawn. It is also impossible to estimate the kind of connection in which the possible increase in yield due to the phosphate fertilization and the changes in the organic $\mathrm{P}$ content of the soil are with each other. These are questions which must wait for further investigation.

\section{$S u m m$ ar $y$}

In the present paper the results of a preliminary study of the accumulation of fertilizer $\mathrm{P}$ in peat soils is reported. The material consisted of samples from an old field experiment in Leteensuo Experiment Station and from 12 experiments on newly reclaimed soils in Northern Finland.

The primary object of this paper was the consideration of the role of organic $\mathrm{P}$ in the accumulation of fertilizer phosphate. Some support was obtained to the assumption that the biological absorption of $\mathrm{P}$ performed by microorganisms and plants stores up in organic form a large part of phosphorus applied to peat soils. 
The fertilizer $\mathrm{P}$ accumulated in inorganic forms was generally rather tenaceously fixed. The retention of phosphate against extraction with $0.05 \mathrm{~N} \mathrm{NaCl}$ solution was high in most of the peat samples.

\section{Acknowledgement}

The authors wish to express their gratitude to Dr. Aimo Isotalo for providing the samples from the field experiment in Leteensuo and to Mr. Jaakko Kivekäs M.S. for the samples from the experiments in Northern Finland.

\section{REFERENCES}

(1) Bradley, D. B. \& Sieling, D. H. 1953. Effect of organic anions and sugars on phosphate precipitation by iron and aluminum as influenced by $\mathrm{pH}$. Soil Sci. $76: 175-179$.

(2) Doughty, J. L. 1930. The fixation of phosphate by a peat soil. Ibid. 29: $23-35$.

(3) —- 1935. Phosphate fixation in soils, particularly as influenced by organic matter. Ibid. 40: $191-202$.

(4) Jackman, R. H. 1951. Phosphorus status of some pumice soils. New Zealand Grassland Assoc. 13th Ann. Conf. 1951: 176-186.

(5) —- 1955. Organic phosphorus in New Zealand soils under pasture: I. Conversion of applied phosphorus into organic forms. Soil Sci. 79: 207-213.

(6) KaIla, A. 1948. Viljelysmaan orgaanisesta fosforista. (Summary: On organic phosphorus in cultivated soils.) Valt. maatal.koetoim. julk. 129. Helsinki.

(7) - $\rightarrow$ 1955. Studies on the colorimetric determination of phosphorus in soil extracts. Acta agr. fenn. $83: 25-47$.

(8) $\rightarrow-1956$. Determination of the degree of humification in peat samples. J. Sci. Agr. Soc. Finland 28: $18-35$.

(9) —- \& Virtanen, O. 1955. Determination of organic phosphorus in samples of peat soils. Ibid. 27: $104-115$.

(10) Kasakow, E. 1934. Adsorption der Phosphate durch Moorböden. Pedology 29: 493. (Ref. Zeitschr. Pflanzenern., Düng. u. Bodenk. 41: 105.)

(11) Kurtz, L. T. 1953. Inorganic phosphorus in acid and neutral soils. Agronomy 4: 59-88.

(12) Mattson, S. 1931. The laws of soil colloidal behavior: IV. Isoelectric precipitates. Soil Sci. 31: $57-77$.

(13) McCool, M. M. 1921. Peat and muck soils. Fixation of fertilizers. Mich. Quart. Bul. 3: 127.

(14) WILd, A. 1950. The retention of phosphate by soil. A review. J. Soil. Sci. 1: 221-238.

\section{SELOSTUS:}

\section{LANNOITEFOSFORIN KERTYMISESTÄ TURVEMAIHIN}

Armi Kaila ja Hilve Missilä

Yliopision maanviljelyskemian laitos, Helsinki

Tutkitut turvemaitten lannoituskokeitten näytteet osoittivat, että vuotuinen superfosfaattilannoitus kohottaa yleensä sekä orgaanisen että epäorgaanisen fosforin määrää maassa verrattuna vas- 
taavaan lannoittamattomaan koejäseneen. Orgaanisen fosforin kertyminen maahan johtunee sekä kasvien että mikrobien aiheuttamasta biologisesta pidättymisestä. Epäorgaanisessa muodossa maahan jäänyt fosfori oli yleensä verraten vaikeasti liukenevaa. Rautayhdisteillä näyttää olevan merkitystä turpeiden tehokkaassa fosfaatin pidättämisessä. 